\title{
Growth performance of Astyanax altiparanae fed with plant and/or animal lipid sources
}

\author{
Dinámica de crecimiento de Astyanax altiparanae alimentado con \\ fuentes de lípidos de plantas y / o animales
}

\begin{abstract}
William Chaves ${ }^{1}$, Érica C. Almeida ${ }^{2}$, Cristiana L. S. Carneiro ${ }^{3}$, Larisa Magnone ${ }^{4}$, Nilton J. T. Martins ${ }^{5}$, Martin Bessonart ${ }^{6}$, Jener A. S. Zuanon ${ }^{7}$, Ana L. Salaro ${ }^{8}$
\end{abstract}

\begin{abstract}
ARTICLE DATA
${ }^{1}$ M.Sc Universidade Federal de Viçosa, Viçosa, Brazil. williamchaveszootecnista@gmail.com

${ }^{2}$ Zootechnical student, Universidade Federal de Viçosa, Viçosa, Brazil. erica.caroline@ufv.br

${ }^{3}$ M.Sc, Universidade Federal de Viçosa, Viçosa, Brazil. cristiana.carneiro@ufv.br

${ }^{4}$ M.Sc, Universidad de la República, Montevideo, Uruguay.larisa@fcien.edu.uy

${ }^{5}$ Zootechnical student, Universidade Federal de Viçosa, Viçosa, Brazil. niltonjuniormartins@gmail. com

${ }^{6}$ Universidad de la República, Montevideo, Uruguay. martinb@fcien.edu.uy

7 D.Sc Teacher, Universidade Federal de Viçosa, Viçosa, Brazil. jenerzuanon@gmail.com

${ }^{8}$ D.Sc Teacher, Universidade Federal de Viçosa, Viçosa, Brazil. salaro@ufv.br

Cite: Chaves, W., Almeida, E., Carneiro, C., Magnone, L., Martins, N., Bessonart, M., Zuanon, J. \& Salaro, A. (2019). Growth performance of Astyanax altiparanae fed with plant and/or animal lipid sources. Revista de Ciencias Agrícolas. 36(E): 63-70. doi: https://doi. org/10.22267/rcia.1936E.107
\end{abstract}

Received: August 132019.

Accepted: September 272019.

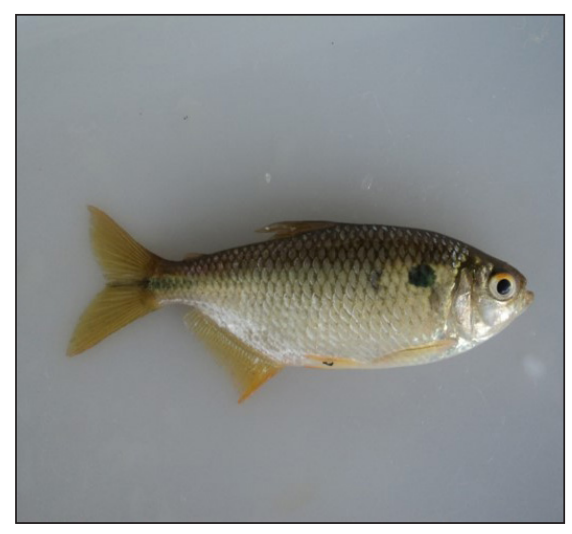

ABSTRACT

The lambari, Astyanax altiparanae, exhibits a great potential for aquaculture due to its omnivory, rapid growth and ease captive production. Despite of fish lipid metabolism being directly related to the dietary lipid consumed, which may lead to changes in fish growth, nothing much have been established regarding the lipid sources that can be applied in A. altiparanae captive production. Thus, this present research was conducted aiming to evaluate the growth performance and whole body composition of A. altiparanae fed with lipid sources of plant and/or animal origins. Were used a Completely Randomized design experiment with five treatments. The treatments consisted of isoproteic and isoenergetic diets, containing the following lipid sources: T1: linseed, chia and sunflower oils; T2: linseed and corn oils; T3: linseed, chia, corn and sunflower oils; T4: sunflower, corn and fish oils; T5: linseed, chia, sunflower, corn oils and bovine fat. Each treatment was replicated six times, where the experimental units consists of 10 fishes (averaged weight: $4.0+0.5 \mathrm{~g}$ ) placed in an aquarium containing $80 \mathrm{~L}$ of dechlorinated water. Were compared the growth performance parameters among the treatments by applying an oneway analysis of variance (ANOVA) at $5 \%$ significance $(P<0.05)$. The results revealed that both growth performance and whole body composition of $A$. altiparanae were not affected by the lipid source, which indicate that these fishes can efficiently use both vegetable lipid sources as well as mixtures of vegetable and animal lipid sources without any growth disadvantages.

Keywords: bovine fat, fish nutrition, neotropical fish, vegetable oils.

\section{RESUMEN}

El lambari, Astyanax altiparanae, exhibe un gran potencial para la acuicultura debido a su crecimiento omnívoro, rápido y fácil de cautiverio. A pesar de que el metabolismo de los lípidos en los peces está directamente relacionado con los lípidos de la dieta, lo que puede conducir a cambios en el crecimiento de los peces, no se ha establecido mucho sobre las fuentes de lípidos que se pueden aplicar en la producción en cautiverio de A. altiparanae. Por lo tanto, esta investigación se realizó con el objetivo de evaluar el rendimiento del crecimiento y la composición del cuerpo de A. altiparanae alimentados con fuentes de lípidos de origen vegetal y animal. Se utilizó un experimento de diseño completamente al azar con cinco tratamientos. Los tratamientos consistieron en dietas isoproteicas e isoenergéticas, que contenían las siguientes fuentes de lípidos: T1: aceites de linaza, chía y girasol; T2: aceites de linaza y maíz; T3: aceites de linaza, chía, maíz y girasol; T4: girasol, maíz y aceites de pescado; T5: linaza, chía, girasol, aceites de maíz y grasa bovina. Cada tratamiento se repitió seis veces, las unidades experimentales consisten en 10 peces (peso promedio: $4.0+0.5 \mathrm{~g}$ ) colocados en un acuario que contiene 
Chaves et al. - Lipid sources for A. altiparanae production.

80 litros de agua desclorada. Se compararon los parámetros de rendimiento de crecimiento entre los tratamientos mediante la aplicación de un análisis de varianza unidireccional (ANOVA) con una significancia del $5 \%(\mathrm{P}<0.05)$. Los resultados revelaron que tanto el rendimiento del crecimiento como la composición del cuerpo de A. altiparanae no se vieron afectados por la fuente de lípidos, lo que indica que estos peces pueden usar eficientemente tanto fuentes de lípidos vegetales como mezclas de fuentes de lípidos vegetales y animales sin ninguna desventaja de crecimiento.

Palabras clave: Grasas bovinas, nutrición de peces, peces neotropicales, aceites vegetales

\section{INTRODUCTION}

Among the Neotropical fish species, the lambari, Astyanax altiparanae, has been highlighted as one of the most relevant species for the Latin American aquaculture (Campelo et al., 2018) as its production has served not only for human consumption but also for the live bait market. The omnivorous feeding habit of A. altiparanae also favors its captive breeding. Furthermore, the $A$. altiparanae has several advantages (e.g., rapid growth, short life cycle, ease of captive production associated with its small size) that contribute to this species potential as an experimental organism model (Pontes et al., 2019), which means that studies conducted with A. altiparanae can support the production of other fish species of commercial interest, especially those of omnivorous eating habits.

Aquaculture is still dependent on ingredients from industrial fisheries such as fishmeal and fish oil (Tacon and Metian, 2008) as these ingredients are relevant sources of energy (Bell et al., 2003) and rich fatty acids such arachidonic (ARA; 20: 4n6), eicosapentaenoic (EPA; 20: 5n6) and docosapentaenoic (DHA; 22: 6n3) (Ng and Wang, 2011). However, in recent years, there has been a decline in industrial fishery resources, causing fluctuations in these products' supplies and prices, which has raised discussions about potential alternative sources to replace fish oils (Bell et al., 2002; Turchini et al., 2010; Tacon and Metian, 2015). Among the ingredients that may replace fish oil as lipid source, the vegetable oils has presented considerable potential. However, the vegetable oils are usually poor in fatty acids such as ARA, EPA and DHA (Paulino et al., 2018).

Some tropical fish species are capable of synthesizing ARA, EPA and DHA from fatty acid precursors as the linolenic (18: $3 \mathrm{n} 3$ ) and linoleic (18: 2n6) acids (Tocher, 2015) that must be presented in their diets. However, enzymes that act on the bioconversion of fatty acids have higher affinity for $\mathrm{n} 3$ series fatty acids (Henderson and Tocher, 1987), which may lead to higher EPA formation compared to ARA formation (Bell and Koppe, 2010), reinforcing the idea that the diets has to present adequate dietary ratios of precursor for $n 3$ and $n 6$ fatty acids.

The fishes' fatty acid profiles are directly related to the profile of their consumed diets (Tocher, 2010). Alteration in dietary fatty acid profiles may influence fish lipid metabolism, which can lead to changes in growth, carcass fatty acid profile and centesimal composition (Bell et al., 2002; Castro et al., 2016). Thus, this study was conducted aiming to evaluate the growth performance and whole body composition of A. altiparanae fed on diets containing different sources of saturated and unsaturated fatty acids.

\section{MATERIAL AND METHODS}

This study was conducted at the Fish Bioclimatology and Nutrition Laboratory of the Fish Farming Sector at the Universidade Federal de Viçosa (UFV), Minas Gerais, Brazil $\left(20^{\circ} 45^{\prime} \mathrm{S}, 42^{\circ} 52^{\prime} \mathrm{W}\right)$ and was approved by CEUAP (2017), protocol 017/2017. 
A completely randomized experimental design with five treatments and six replications was used. The treatments consisted of five isoproteic (300.46g crude protein $\mathrm{kg}^{-1}$ diet) and isoenergetic $(4353.4 \mathrm{kcal}$ crude energy $\mathrm{kg}^{-1}$ diet) diets that contained different lipid sources. Were used the following treatments:
T1) linseed, chia and sunflower oils; T2) linseed and corn oils; T3) linseed, chia, corn and sunflower oils; T4) sunflower, corn and fish oils; T5) linseed, chia, sunflower, corn oils and bovine fat. The percentage composition, chemistry and fatty acid profile of the diets are shown in Table 1 and Table 2.

Table 1. Formulation and composition of experimental diets containing different lipid sources.

\begin{tabular}{|c|c|c|c|c|c|}
\hline \multirow{2}{*}{ Ingredients ( $\mathrm{g} \mathrm{kg}^{-1}$ ) } & \multicolumn{5}{|c|}{ Treatments } \\
\hline & T1 & $\mathrm{T} 2$ & T3 & T4 & T5 \\
\hline Soybean meal & 437.0 & 437.0 & 437.0 & 437.0 & 437.0 \\
\hline Fish meal & 120.0 & 120.0 & 120.0 & 120.0 & 120.0 \\
\hline Corn flour & 220.0 & 220.0 & 220.0 & 220.0 & 220.0 \\
\hline Wheat flour & 85.0 & 85.0 & 85.0 & 85.0 & 85.0 \\
\hline Inert & 4.3 & 4.3 & 4.3 & 4.3 & 4.3 \\
\hline Cellulose & 2.5 & 2.5 & 2.5 & 2.5 & 2.5 \\
\hline L - Lysine & 2.0 & 2.0 & 2.0 & 2.0 & 2.0 \\
\hline DL - Methionine & 10.0 & 10.0 & 10.0 & 10.0 & 10.0 \\
\hline Bicalcium phosphate & 26.5 & 26.5 & 26.5 & 26.5 & 26.5 \\
\hline Salt & 2.5 & 2.5 & 2.5 & 2.5 & 2.5 \\
\hline Premix vit/min ${ }^{1}$ & 10.0 & 10.0 & 10.0 & 10.0 & 10.0 \\
\hline BHT $^{2}$ & 0.2 & 0.2 & 0.2 & 0.2 & 0.2 \\
\hline Linseed oil & 40.0 & 20.0 & 30.0 & 0.0 & 5.7 \\
\hline Chia Oil & 20.0 & 0.0 & 10.0 & 0.0 & 0,35 \\
\hline Sunflower oil & 20.0 & 0.0 & 10.0 & 22.0 & 1.9 \\
\hline Corn oil & 0.0 & 60.0 & 3,00 & 18.0 & 5.7 \\
\hline Fish oil & 0.0 & 0.0 & 0.0 & 4.0 & 0.0 \\
\hline Bovine fat & 0.0 & 0.0 & 0.0 & 0.0 & 63.2 \\
\hline \multicolumn{6}{|l|}{ Chemical composition $\left(\mathrm{g} \mathrm{kg}^{-1}\right)$} \\
\hline Dry matter $\left(\mathrm{g} \mathrm{kg}^{-1}\right)$ & 923.8 & 919.9 & 905.4 & 922.2 & 908.7 \\
\hline Crude energy (kcal kg-1) & 4399 & 4402 & 4069 & 4338 & 4459 \\
\hline Crude protein ( $\mathrm{g} \mathrm{kg}^{-1}$ of DM) & 312.1 & 294.6 & 301.4 & 310.9 & 304.0 \\
\hline Ether extract ( $\mathrm{g} \mathrm{kg}^{-1}$ of DM) & 86.9 & 68.1 & 68.1 & 86.4 & 64.1 \\
\hline Ash (g kg-1 of DM) & 86.8 & 85.6 & 85.8 & 87.2 & 85.2 \\
\hline
\end{tabular}

${ }^{1}$ Warranty levels per kilogram of product (Supremais, Campinas/SP, Brazil): Vit. A = 1.200.000 IU; Vit. D3 = 200.000 IU; Vit. E = 12.000 mg; Vit. K3 = 2.400 mg; Vit. B1 = 4.800 mg; Vit. B2 = 4.800 mg; Vit. B6 $=4.000 \mathrm{mg}$; Vit. B12 $=4.800 \mathrm{mg}$; folicacid $=1.200 \mathrm{mg}$; calciumpantothenate $=12.000 \mathrm{mg}$; Vit. C $=48.000 \mathrm{mg}$; Biotin $=48 \mathrm{mg}$; Choline $=65.000 \mathrm{mg}$; Nicotinicacid $=24.000 \mathrm{mg} ; \mathrm{Fe}=10.000 \mathrm{mg} ; \mathrm{Cu}=$ $6.000 \mathrm{mg} ; \mathrm{Mn}=4.000 \mathrm{mg} ; \mathrm{Zn}=6.000 \mathrm{mg} ; \mathrm{I}=20 \mathrm{mg} ; \mathrm{Co}=2 \mathrm{mg} ; \mathrm{Se}=20 \mathrm{mg} .{ }^{2}$ Butylatedhydroxytoluene (antioxidant). DM: dry matter. T1: linseed, chia and sunflower oils; T2: linseed and corn oils; T3: linseed, chia, corn and sunflower oils; T4: sunflower, corn and fish oils; T5: linseed, chia, sunflower, corn oils and bovine fat. 
Table 2. Fatty acid profiles of experimental diets containing different lipid sources.

\begin{tabular}{|c|c|c|c|c|c|}
\hline & \multicolumn{5}{|c|}{ Fatty acids ( $\mathrm{g} \mathrm{kg}^{-1}$ of total identified fatty acids) } \\
\hline & T1 & $\mathrm{T} 2$ & T3 & T4 & T5 \\
\hline $12: 0$ & 0.1 & 0.0 & 0.0 & 0.1 & 0.1 \\
\hline $14: 0$ & 0.4 & 0.2 & 0.2 & 1.3 & 2.1 \\
\hline $15: 0$ & 0.1 & 0.0 & 0.1 & 0.3 & 0.4 \\
\hline $16: 0$ & 7.7 & 10.7 & 9.0 & 12.1 & 19.9 \\
\hline $17: 0$ & 0.0 & 0.1 & 0.3 & 0.3 & 0.5 \\
\hline 18:0 & 4.3 & 3.3 & 3.9 & 3.1 & 18.2 \\
\hline 23:00 & 0.0 & 0.0 & 0.0 & 0.2 & 0.0 \\
\hline $24: 00$ & 0.0 & 0.1 & 0.1 & 0.5 & 0.0 \\
\hline $14: 1$ & 0.0 & 0.0 & 0.0 & 0.2 & 0.6 \\
\hline $16: 1$ & 0.5 & 0.8 & 0.6 & 3.0 & 2.1 \\
\hline $18: 1$ & 31.8 & 29.2 & 29.9 & 39.2 & 32.5 \\
\hline $20: 1 n 9$ & 0.4 & 0.5 & 0.4 & 1.3 & 0.5 \\
\hline $22: 1 n 9$ & 0.1 & 0.2 & 0.2 & 0.5 & 0.0 \\
\hline $18: 2 \mathrm{n} 6$ & 17.6 & 40.3 & 27.6 & 19.8 & 11.1 \\
\hline $18: 3 n 3$ & 34.6 & 12.8 & 23.9 & 1.4 & 6.6 \\
\hline 20:4n6 (ARA) & 0.0 & 0.0 & 0.2 & 0.7 & 0.1 \\
\hline 20:5n3 (EPA) & 0.6 & 0.5 & 0.6 & 3.8 & 0.5 \\
\hline 22:6n3 (DHA) & 0.4 & 0.3 & 0.3 & 7.5 & 0.3 \\
\hline$\Sigma \mathrm{SAFA}$ & 12.55 & 14.50 & 13.47 & 17.90 & 41.32 \\
\hline ¿MUFA & 33.23 & 30.78 & 31.59 & 46.30 & 36.47 \\
\hline$\Sigma$ PUFA & 54.22 & 54.72 & 54.94 & 35.80 & 22.22 \\
\hline n3 & 32.34 & 30.03 & 27.23 & 37.00 & 31.16 \\
\hline n6 & 17.61 & 40.79 & 28.10 & 20.69 & 11.85 \\
\hline n6/n3 & 0.49 & 2.96 & 1.11 & 1.53 & 1.37 \\
\hline
\end{tabular}

¿SAFA: sum of saturated fatty acids; $\Sigma$ MUFA: sum of monounsaturated fatty acids; $\Sigma$ PUFA: sum of polyunsaturated fatty acids. T1: linseed, chia and sunflower oils; T2: linseed and corn oils; T3: linseed, chia, corn and sunflower oils; T4: sunflower, corn and fish oils; T5: linseed, chia, sunflower, corn oils and bovine fat.

In order to avoid potential interference of the fatty acid macro-ingredients profiles, the soybean and wheat bran, the fishand cornmeals were degreased before experimental diets were prepared. To this, three liters of chloroform was added for each kilo of ingredient. After mixing the mixture
(3 min), it was vacuum filtered through a Büchner funnel (with filter paper) connected to a Kitasato flask. This process was repeated three times for each ingredient and the solid material was dried at room temperature. After degreasing, the macro-ingredients were milled in hammer mills (with $0.5 \mathrm{~mm}$ diameter 
sieve) and were manually mixed with the micro-ingredients and the different oil source proportions. The diets were pelletized in a meat grinder (FILIZOLA, P-22, São Paulo, SP, Brazil), dried in a forced ventilation oven (Marconi Equipamentos para Laboratórios, MA 035, Piracicaba, SP, Brasil) at $50^{\circ} \mathrm{C}$, ground in a manual mill (BOTIMETAL , Bilac, SP, Brazil) and sifted to obtain $0.8 \mathrm{~mm}$ pellets.

The analyzes for chemical composition and fatty acid profiles of the diets were conducted, respectively, at the Food Analysis Laboratory of the Department of Animal Science (at UFV) and at the Natural Resources Laboratory of the Institute of Ecology and Environmental Science at Republic University, Montevideo, Uruguay.

Three hundred A. altiparane specimens (average weight of $4.0+0.5 \mathrm{~g}$ ) were distributed in 30 aquariums (80L) containing $50 \mathrm{~L}$ of dechlorinated water, at a density of 10 fishes per aquarium. The aquariums were maintained in a $2.5 \mathrm{~L} \mathrm{~min} \mathrm{~m}^{-1}$ flow recirculation system, and were equipped with mechanical and biological filters, constant aeration and thermostatically controlled heating. The experimental units were covered with white nylon mesh $(2 \mathrm{~mm})$ to prevent fish escaping. The laboratory was maintained at a $12 \mathrm{~h}$ photoperiod by using fluorescent lamps (60 watts) controlled by analog timer. The water temperature $\left(28 \pm 0.5^{\circ} \mathrm{C}\right)$ was daily measured, before each feeding, by means of a common alcohol thermometer $\left(0\right.$ to $\left.100^{\circ} \mathrm{C}\right)$. The $\mathrm{pH}(7.0$ $+0.2)$ and total ammonia $(0.22+0.20 \mathrm{ppm})$ parameters were weekly measured by using colorimetric kits, and dissolved oxygen (6.5 $+0.5 \mathrm{mg} \mathrm{L}^{-1}$ ) measurement was achieved by an ProPlus Multiparameter Equipament (YSI incorporated, Yellow Springs, OH, USA).

The fish were manually fed for nine weeks, three times a day (8:00 am, 12:00 am and 5:00 pm) until apparent satiety. At the end of the experiment, the fish were euthanized using a clove, Syzygium aromaticum, essential oil overdose (400mg L-1) and weighed on an analytical balance (MB45 Toledo $® 0.01 \mathrm{~g}$, São Bernardo do Campo, SP, Brazil) with $0.01 \mathrm{~g}$ accuracy to evaluate the following zootechnical variables: Weight Gain = Final Weight - Initial Weight, Specific Growth Rate = [(ln final weight - ln initial weight) X 100]/time (in days), Carcass Yield $=$ [(final weight - offal weight) / final weight] X 100, Hepatosomatic Index = (liver weight / final weight) $\mathrm{x} 100$, Viscerosomatic Index $=$ (viscera weight $/$ final weight) $\mathrm{x} 100$, Visceral fat index $=$ (visceral fat weight / final weight) x 100 .

For the whole body composition, a fish pool from each treatment was dried in a forced ventilation oven at $60^{\circ} \mathrm{C}$ for $24 \mathrm{~h}$. The samples were processed in a ball mill (Botimetal, Bilac, SP, Brazil Brazil). By following methodologies previously described elsewhere (Detmann et al., 2012), we determined the crude protein, crude energy, ether extract, dry matter and ash contents.

The obtained data were submitted to the Lilliefors test to verify the normality of the errors and the Bartlett test to verify the homogeneity of the variances. All the results were subjected to an unidirectional analysis of variance (ANOVA) with significance of $5 \%(P<0.05)$, and when needed, the mean comparison test (Tukey test, $P<0.05$ ) was applied. All statistical analyzes were conducted by using the estatistical software $\mathrm{R}$ (version 3.3).

\section{RESULTS AND DISCUSSION}

In this study, no differences $(\mathrm{P}>0.05)$ were observed in the weight gain, specific growth rate, carcass yield and hepatosomatic, viscerosomatic and visceral fat indices in fish fed diets containing different lipid sources (Table 3 ). These results show that $A$. altiparanae can efficiently use lipid sources of plant and animal origin for both energy and fatty acid supplies. 
Chaves et al. - Lipid sources for A. altiparanae production.

Table 3. Growth performance of Astyanax altiparanae fed on diets containing different sources of saturated and unsaturated fatty acids.

\begin{tabular}{lcccccc}
\hline \multicolumn{1}{c}{ Variables } & T1 & T2 & T3 & T4 & T5 & CV (\%) \\
\hline Weight gain (g) $^{\text {ns }}$ & $0.81 \pm 0.25$ & $0.54 \pm 0.09$ & $0.55 \pm 0.29$ & $0.59 \pm 0.20$ & $0.74 \pm 0.23$ & 32.9 \\
${\text { Specific Growth Rate (\%/ dia) }{ }^{\text {ns }}}^{0}$ & $0.31 \pm 0.06$ & $0.21 \pm 0.04$ & $0.25 \pm 0.07$ & $0.23 \pm 0.07$ & $0.29 \pm 0.01$ & 27.47 \\
Carcass Yield (\%) $^{\text {ns }}$ & $79.38 \pm 1.98$ & $81.75 \pm 1.81$ & $81.28 \pm 2.43$ & $80.17 \pm 2.27$ & $82.0 \pm 2.54$ & 2.68 \\
Hepatosomatic Index (\%) $^{\text {ns }}$ & $0.71 \pm 0.16$ & $0.76 \pm 0.13$ & $0.75 \pm 0.18$ & $0.75 \pm 0.18$ & $0.78 \pm 0.14$ & 26.56 \\
Viscerosomatic Index (\%) $^{\text {ns }}$ & $16.31 \pm 2.04$ & $12.69 \pm 2.05$ & $13.19 \pm 2.46$ & $14.76 \pm 2.57$ & $15.33 \pm 2.67$ & 16.29 \\
Visceral Fat Index (\%) $^{\mathrm{ns}}$ & $1.24 \pm 0.75$ & $1.67 \pm 0.35$ & $1.66 \pm 0.23$ & $1.70 \pm 0.42$ & $1.76 \pm 0.20$ & 26.57 \\
\hline
\end{tabular}

ns: not significant; CV: coefficient of variation. T1: linseed, chia and sunflower oils; T2: linseed and corn oils; T3: linseed, chia, corn and sunflower oils; T4: sunflower, corn and fish oils; T5: linseed, chia, sunflower, corn oils and bovine fat.

Since lipids are the main source of digestible energy for fishes (Lim et al., 2011), the sources used in the present investigation probably supplied the A. altiparanae fatty acid requirements. The complete replacement of fish oil by the mixture containing soybean and linseed oils also did not affect the performance of these fishes in previous investigation (Pontes et al., 2019). These findings are similar to these ones described for other fish species such as surubim (Pseudoplatystoma coruscans) (Martino et al., 2002), panga (Pangasius hypophthalmus) (Asdari et al., 2011), murray cod (Macullochella peelii peelii) (Turchini et al., 2011) and Nile tilapia (Oreochromis niloticus) (Ng et al., 2013), where diets containing vegetable lipid sources did not negatively affect the fish growth.

Such lack of differences in the A. altiparanae performance fed in our experimental diets may also be associated with the omnivorous eating habits of these animals. Astyanax altiparanae, like most of other especies belonging to the Genus, is an omnivorous species that can feed on algae, insects (eggs, larvae and adults) as well as fruits and seeds (Vazzoler and Menezes, 1992; Vaz et al., 2000). Therefore, these fihses are well knowing for having high feeding flexibility (Abilhoa, 2007). It is also possible that tested fishes have adapted to the different sources of lipids used, which resulted in the absence of growth losses.

Another possible explanation for our findings would be the fatty acid ratios of the $n 6$ and n3 series of tested diets, which although composed of different lipid sources were efficient in providing the requirements for essential fatty acids for A. altiparanae. For investigations unsing other omnivorous eating habit fishes, diets containing different $\mathrm{n} 6 / \mathrm{n} 3$ ratios were not capable of interfering in the fish production performance (Paulino et al., 2018). Similar results were also observed for carnivorous species such as murray cod Maccullochella peelii peelii (Senadheera et al., 2010) and rainbow trout, Oncorhynchus mykiss (Thanuthong et al., 2011) when these fishes fed on diets containing different n6/ n3 fatty acid ratios obtained from mixtures of vegetable oils. As demonstrated for these omnivorous/carnivorous previous fish species, our results for fish whole body compositions were unaffected by the tested diets (Table 4). However, for the same species in this study, the total replacement of fish 
oil with vegetable oil mixtures altered the carcass lipid content (Pontes et al., 2019). In addition, fish fed the diet containing only linseed oil had the lowest fat deposition in the carcass (Pontes et al., 2019).

The use of alternative sources to fish meal and oils without harming the animals has becomea fundamental tool for the aquaculture growth, especially regarding the sustainability of production. Such aspects becomes even more relevant given the sharp decline in fishery resources, which has caused fluctuations in the supply and price of both fish meal and oils (Bell et al., 2002; Turchini et al., 2010; Tacon and Metian, 2015).

\section{CONCLUSIONS}

A. altiparanae can efficiently use both lipid sources of vegetable origin (alone or mixed with animal-originated oils) without exibiting any growth disadvantages.

\section{ACKNOWLEDGMENTS}

The authors would like to acknowledge the financial support of CAPES Foundation (Financial code 001), the National Council of Scientific and Technological Development (CNPq, especially for the Scientific Productiity Scholarship for ALS, No. 304975/20176) and the Minas Gerais State Foundation for Research Aid and Scientific Initiation Scholarship for ECA (FAPEMIG).

\section{BIBLIOGRAPHIC REFERENCES}

Abilhoa, V. (2007). Aspectos da história natural de Astyanax scabripinnis Jenyns (Teleostei, Characidae) em um riacho de floresta com araucária no sul do Brasil. Rev. Bras. Zool., 24(4): 997-1005. doi: http://dx.doi. org/10.1590/S0101-81752007000400016
Asdari, R., Aliyu-Paiko, M., Hashim, R., \& Ramachandran, S. (2011). Effects of different dietary lipid sources in the diet for Pangasius hypophthalmus (Sauvage, 1878) juvenile on growth performance, nutrient utilization, body indices, muscle and liver fatty acid composition. Aquac. Nutr. 17(1): 44-53. doi: https://doi.org/10.1111/j.13652095.2009.00705.x

Bell, J. G., \& Koppe, W. (2010). Lipids in aquafeeds. In: Turchini, G. M., Ng, W. K., \& Tocher, D. R. Fish oil replacement and alternative lipid sources in aquaculture feeds. pp. 21-59. First edition. Flórida: EUA. 249 p.

Bell, J. G., Henderson, R. J., Tocher, D. R., McGhee, F., Dick, J. R., Porter, A. \& Sargent, J. R. (2002). Substituting fish oil with crude palm oil in the diet of Atlantic salmon (Salmo salar) affects muscle fatty acid composition and hepatic fatty acid metabolism. J. Nutr. 132(2): 222-230. doi: https://doi.org/10.1093/jn/132.2.222

Bell, J. G., McGhee, F., Campbell, P. J., \& Sargent, J. R. (2003). Rapeseed oil as an alternative to marine fish oil in diets of post-smolt Atlantic salmon (Salmo salar): changes in flesh fatty acid composition and effectiveness of subsequent fish oil "wash out". Aquacult. 218(1-4): 515528. doi: https://doi.org/10.1016/S00448486(02)00462-3

Campelo, D.A.V., Salaro, A.L., Ladeira, A.L.F., Moura, L.B.D., \& Furuya, W.M. (2018). Dietary lysine requirement of adult lambari (Astyanax altiparanae) (Garutti and Britski, 2000). $R$. Bras. Zootec., 47: e20160325. doi: http:// dx.doi.org/10.1590/rbz4720160325

Castro, C., Corraze, G., Firmino-Diógenes, A., Larroquet, L., Panserat, S., \& Oliva-Teles, A. (2016). Regulation of glucose and lipid metabolism by dietary carbohydrate levels and lipid sources in gilthead sea bream juveniles. Brit. J. Nutr., 116(1):1934. doi: https://doi.org/10.1017/ S000711451600163X

CEUAP- Comissão de Ética no Uso de Animais de Produção (2017). Protocol 017/2017. Retrieved from URL

Henderson, R. J. \& Tocher, D. R. (1987). The lipid composition and biochemistry of freshwater fish.Prog. Lipid.Res. 26(4):281-347. doi: https:// doi.org/10.1016/0163-7827(87)90002-6 
Chaves et al. - Lipid sources for A. altiparanae production.

Lim, C., Yildirim-Aksoy, M., \& Klesius, P. (2011). Lipid and fatty acid requirements of tilapias. $N$. Am. J. Aquacult. 73(2): 188-193. doi: https:// doi.org/10.1080/15222055.2011.579032

Martino, R.C., Cyrino, J.E.P., Portz, L. \& Trugo, L.C. (2002). Performance and fatty acid composition of surubim (Pseudoplatystoma coruscans) fed diets with animal and plant lipids. Aquacult. 209(1-4): 233-246. doi: https:// doi.org/10.1016/S0044-8486(01)00847-X

Ng, W. K., \& Wang, Y. (2011). Inclusion of crude palm oil in the broodstock diets of female Nile tilapia, Oreochromis niloticus, resulted in enhanced reproductive performance compared to broodfish fed diets with added fish oil or linseed oil. Aquacult. 314(1-4): 122-131. doi: https://doi.org/10.1016/j. aquaculture.2011.01.034

Ng, W.K., Chong, C.Y., Wang, Y. \& Romano, N. (2013). Effects of dietary fish and vegetable oils on the growth, tissue fatty acid composition, oxidative stability and vitamin E content of red hybrid tilapia and efficacy of using fish oil finishing diets. Aquacult. 372: 97-110. doi: https://doi. org/10.1016/j.aquaculture.2012.10.030

Paulino, R.R., Pereira, R.T., Fontes, T.V., OlivaTeles, A., Peres, H., Carneiro, D. J. \& Rosa, P.V. (2018). Optimal dietary linoleic acid to linolenic acid ratio improved fatty acid profile of the juvenile tambaqui (Colossoma macropomum). Aquacult. 488: 9-16. doi: https://doi.org/10.1016/j. aquaculture.2018.01.014

Pontes, M.D., Campelo, D.A., Ferraz, R.B., Zuanon, J.A., Furuya, W.M. \& Lucia, S. A. (2019). Soybean and linseed oil in replacement of fish oil in diets for female lambari Astyanax altiparanae Garutti \& Britski, 2000. Lat. Am. J. Aquat. Res. 47(2): 260-269. doi: http://dx.doi. org/10.3856/vol47-issue2-fulltext-6

Senadheera, S.P.S.D., Turchini, G.M., Thanuthong, T. \& Francis, D.S. (2010). Effects of dietary $\alpha$-linolenic acid (18: $3 n-3) /$ linoleic acid (18: $2 n-6)$ ratio on growth performance, fillet fatty acid profile and finishing efficiency in Murray cod. Aquacult. 309(1-4): 222-230. doi: https:// doi.org/10.1016/j.aquaculture.2010.09.039

Tacon, A.G. \& Metian, M. (2008). Global overview on the use of fishmeal and fish oil in industrially compounded aquafeeds: Trends and future prospects. Aquacult. 285(14):146-158. doi: https://doi.org./10.1016/j. aquaculture.2008.08.015

Tacon, A.G. \& Metian, M. (2015). Feed matters: satisfying the feed demand of aquaculture. Rev. Fish Sci. Aquac. 23 (1):110. doi: https://doi.org /10.1080/23308249.2014.987209

Thanuthong, T., Francis, D.S., Manickam, E., Senadheera, S.D., Cameron-Smith, D. \& Turchini, G.M. (2011). Fish oil replacement in rainbow trout diets and total dietary PUFA content: II) Effects on fatty acid metabolism and in vivo fatty acid bioconversion. Aquacult. 322: 99-108. doi: https://doi.org/10.1016/j. aquaculture.2011.09.026

Tocher, D.R. (2010). Fatty acid requirements in ontogeny of marine and freshwater fish. Aquac. Res. 41(5): 717-732. doi: https:// doi.org/10.1111/j.1365-2109.2008.02150.x

Tocher, D.R. (2015). Omega-3 longchain polyunsaturated fatty acids and aquaculture in perspective. Aquacult. 449: 94-107. doi: https://doi.org/10.1016/j. aquaculture.2015.01.010Get rights and content

Turchini, G.M., Ng, W.K., \& Tocher, D.R. (2010). Fish oil replacement and alternative lipid sources in aquaculture feeds. First edition. Boca Raton, New York: CRC Press. 249 p.

Turchini, G.M., Francis, D.S., Senadheera, S., Thanuthong, T. \& De Silva, S.S. (2011). Fish oil replacement with different vegetable oils in Murray cod: evidence of an "omega-3 sparing effect" by other dietary fatty acids.Aquacult.315(3-4):250-259.doi:https:// doi.org/10.1016/j.aquaculture.2011.02.016

Vaz, M.M., Torquato, V.C., Barbosa, N. (2000). Guia ilustrado de peixes da bacia do Rio Grande. CEMIG: CETEC, Belo Horizonte. 144p.

Vazzoler, A.E., \& Menezes, N.A. (1992). Síntese de conhecimentos sobre o comportamento reprodutivo dos Characiformes da América do Sul (Teleostei, Ostariophysi). Rev. Bras. Biol. 52(4): 627-40. 